\title{
Melissa Moore
}

\section{What's in a name?}

\section{Becoming a coach in a university library}

$I^{\text {hitis }}$

ave a new title. Not a new job. Just a new itle.

I have been a reference librarian for nearly two decades in an academic library that now serves more than 4,200 students. When I began my career at Union University in 1992, there was a reference desk manned by one professional librarian. Even though I oversaw the circulation desk for the first six or so years of my tenure, I frequently functioned as a reference librarian, conducting classes (we called it bibliographic instruction back then) and doing ready reference from a host of print resources in our reference collection.

These days, my work looks very similar. I collaborate with teaching faculty and do instruction sessions for their classes. I oversee the reference collection, both print and online, and create online tools to assist patrons who will never approach a librarian for help. And even though I no longer staff a reference desk, I assist students nearly every day in the research process. I teach them how to frame their question, choose their keywords, select appropriate databases and the best resources, and properly cite the sources they find. I have always felt at home with this sort of one-on-one assistance, and now I have a title that shows it.

\section{Research coach.}

Nearly two years ago, I was at lunch with two other librarians. As we ate chips and salsa, we lamented the fact that, though we personally felt ourselves to be approachable, we were not getting requests for help. We speculated: was it the result of student belief that everything is in Google? We had seen their work and heard from teaching faculty, that students so often were not using the best resources available in their papers and presentations. Did they have false confidence in their ability to search for resources? We no longer had a reference desk, so was the problem that reference librarians were not visible enough? We just didn't know.

Our conclusion was simple: we didn't want to do students' research for them; we wanted to equip them to do research. Make them lifelong learners. But how?

The answer came in a word-coach. I don't even remember which of the three of us said it, but it clicked immediately. A coach doesn't kick the soccer ball for you, he or she teaches you how to kick, guard, and pass, and then puts you in the game. You learn the skills from the coach, then use them yourself.

So we pitched the idea to our library director, and the game began. One of the other librarians, T. R. Parker, and I became the library's research coaches. We decided what we would do as coaches: predominantly make individual appointments with students, spend some time each week hanging out our shingle in the library to encourage walk-up traffic, and conduct training over the phone for distance students. We worked with our creative projects coordinator to create a logo and come up with different marketing strategies. The research coach was promoted on flatscreen information boards around campus and showcased prominently on the library's Web site. Students are able to request a meeting with a research coach from our Web site through a simple online form, although nearly two years later we get as many appointments from walk-in traffic and repeat customers as we do through the form.

Melissa Moore is research coach/public services librarian at Union University, e-mail: mmoore@uu.edu (c) 2013 Melissa Moore 
We consider it a success. During the fall and spring semesters, Parker and I meet with an average of eight students per week who need the in-depth assistance a research coach provides. We pulled back from advertising it this past semester because we were getting overwhelmed; keep in mind that we have a host of other responsibilities in addition to serving as research coaches.

A typical research coach session runs 30 to 40 minutes, though they can last much longer. And we attribute at least part of that success to the name. Let's face it: the label "librarian" comes with a stereotype, and many of our patrons expect us to be bookish, stuffy types dressed in wool and wearing bifocals. Our students seem very at ease asking if a research coach is available and do it with much more frequency than they ever asked for a librarian. The research coach name has helped us put aside the stereotype and get on with our jobs.

Relationships are being built. Connections are being made. Students are learning how to do research in a more fundamental and thoughtful way than ever before. Students who meet with a coach are invited to give feedback, and their comments are enough to make any librarian's day:

"I was nervous coming in but now I can see that I have a lot of resources available to me. Thanks!"

"The coach was very helpful and patient. She helped broaden my search. Thanks!" "Wonderful!"

Librarians may be scary, but coaches - well, research coaches are "wonderful!"

\section{Note}

1. www.uu.edu/library/research/coach. cfm. $n$

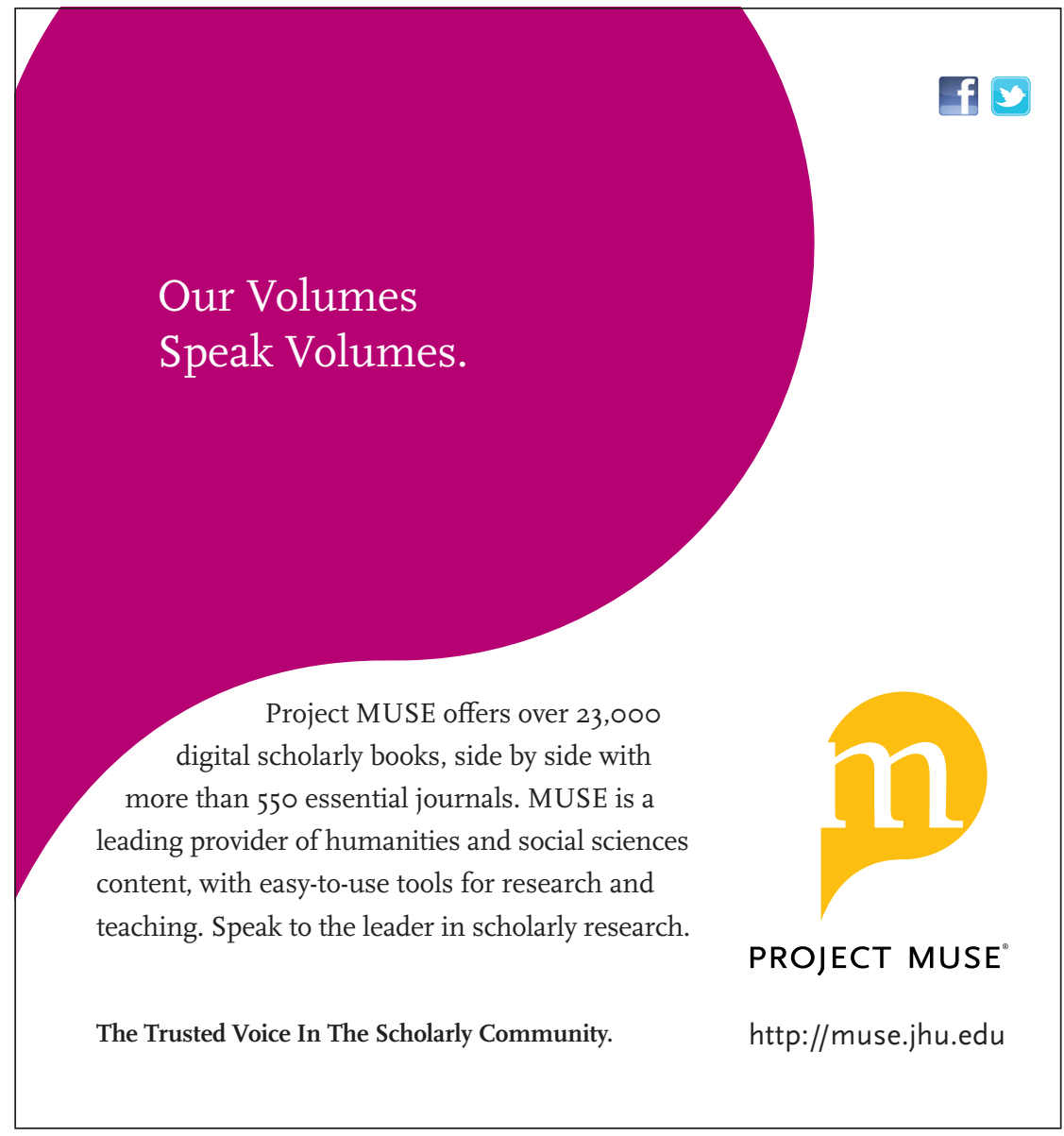

